\title{
The Effect of PBL Model with Technology-Based and Motivation on Student's Entrepreneuraial Attitude of Economics Education Department at STKIP PGRI Jombang
}

\author{
Munawaroh Munawaroh ${ }^{1, *}$ Nanik Sri Setyani ${ }^{2}$, Lina Susilowati ${ }^{3}$ \\ 1,2,3 STKIP PGRI Jombang, Indonesia \\ *Corresponding author.Email: munawarohw@yahoo.co.id
}

\begin{abstract}
The study aimed to The purpose of this study is to determine the impact of problem-based learning (PBL) with technology and learning motivation on students' entrepreneurial attitudes. This study used a quantitative design. The population of this study was 206 students of Economics Education Department at STKIP PGRI Jombang. The sample chosen was 136 students. The data collection methods were observation, interviews, and surveys. The data was analyzed using multiple linear regression. The results showed that 1) there is an effect of the problem-based learning (PBL) model with technology- based on entrepreneurial attitudes 2) there is an influence of Learning motivation on entrepreneurial attitudes 3) there is an influence on entrepreneurial attitudes simultaneously on the problem-based Learning (PBL) model with technology- based and learning motivation. This Research provides practical implications where technology-based PBL provides convenience in managing information related to learning activities during the covid 19 pandemic
\end{abstract}

Keywords: (PBL) Model with Technology-Based, Learning Motivation, Entrepreneurial Attitudes

\section{INTRODUCTION}

Learning in the $21^{\text {st }}$ century has influenced the education system, including the education system in Indonesia. Innovation and educational development must be used to improve learning quality. With Independent Campus, Freedom to Learn, the education system in higher education is designed to encourage higher education institutions and students to disrupt and transform themselves rapidly.

Higher education focuses on 8 (eight) indicators that have the potential to bring higher education potential, such as resources, to interact intensely with the industrial world and the world of work, by inviting industry to enter higher education [1]. Because of the existence of an independent campus, students are required to have individual qualities that are essential for their study and skills that they must master upon graduation. This knowledge encompasses both academic knowledge and the ability (competence) of students to be active, creative, and innovative in their field of study. Every student should be able to apply their knowledge to be successful.
Each student should be able to use his or her knowledge in their daily lives.

This situation applies to all courses, including Entrepreneurship courses. students cannot improve their ability to think critically, creatively, innovatively, and systematically because the learning strategies that encourage critical, creative, innovative, and systematic thinking are not implemented appropriately in the classroom, Students are simply taught how to memorize Entrepreneurship theory, not how to build problemsolving skills in the real world. From the perspective of the Entrepreneurship Class, it is necessary that students be dynamic, motivated, creative, initiative-capable, and think good.

They need to be able to work together on tasks. Unfortunately, most entrepreneurship lecturers use a conventional learning paradigm that includes lectures, questions and answers, and tasks. The conventional learning model has a weakness, such as a lack of interaction between students and a lack of understanding of the teachers' information. 
The conventional models of learning emphasize changes in observable behaviour, but the independent campus curriculum requires changes not only in behaviour but also in critical thinking skills in students. Therefore, teachers need an educational model that doesn't burden students with facts of learning to improve learning results. Entrepreneurship employs a problembased learning model technologically based so that learning can be implemented with various teaching models.

PBL with technology-based is effective at developing questioning, thinking, problem-solving, and independent learning skills. The COVID-19 pandemic has also sparked new ideas for scientists, researchers, lecturers, and students to conduct experiments in order to find innovations and creativity that can present an effective and efficient learning process so that they can engage in some fun learning activities [2]. It also necessitates the transformation and adaption of a variety of learning management tasks [3]. An approach to help students to have understanding and skills that impact learning outcomes is needed. The technology-based PBL paradigm is a student-centered learning model that starts with tasks to gather and integrate new information [4]. At the beginning of the learning process, students are given questions to answer, then they solve problems, and eventually they integrate their knowledge in the form of reports. Students can obtain a better knowledge of theoretical and practical analyses by utilizing PBL with technology.

Higher education is more than just teaching; communication between teachers and students is essential because society grows and develops through social relationships. Student participation in the learning process is not supported by the one-way teaching and learning process. As a result, students must actively participate in the teaching and learning process. Entrepreneurship is an example of a course that requires tight collaboration between students and lecturers [5]. One of several objectives of entrepreneurship in higher education is the ability to analyze and solve problems that are more authentic and concrete than the material presented by lecturers in class; additionally, students receive both soft and hard skill learning, implying that they have knowledge of entrepreneurial concepts and principles as well as the skills to develop them. Students are also learning to think properly and critically as a result of their acquired knowledge and skills.

Several previous studies in Indonesia that examined PBL. Problem -based learning in Entrepreneurship courses is able to stimulate student's learning interest and student self- study activity[6]. According to [7] that problem based learning give influence on Mathematics of students whether for the average of posttest of Mathematics creativities or the average of improvement of Mathematics creativities. Any learning approach based on Problem Based Learning contributes a lot in improving knowledge in the field of learning [8]. [5] found that combining the Problem Based Learning model can help students solve and explore critical thinking skills, their interest in addressing learning challenges and enhance students' entrepreneurial achievement.

An attitude relates to how someone feels or thinks about many areas of entrepreneurship, particularly business, in this subject; the answer might be positive or negative. A person with a positive attitude acts and thinks in a healthy, ideal, and positive manner. In the field of entrepreneurship or business, this positive attitude is defined by the confidence to make decisions and the courage to take risks as a result of those decisions. Entrepreneurial attitudes are a term used to describe people who have this mindset [1]. Anyone who wants to be an entrepreneur must have an entrepreneurial mind set in general. The entrepreneurial attitude is a reflection of the entrepreneurial activity [5]. The study also looked into the relevance and adequacy of course content in university entrepreneurship education to determine the extent to which students' competencies are developed [9]. As a result, as the basic capital in entrepreneurship, college graduates must have an entrepreneurial attitude. Risk-taking, commitment, innovation, self-confidence, and a leadership spirit are all qualities of entrepreneurs [6]. In this regard, entrepreneurship functions as a problem-solving solution for college graduates who are unemployed or living in poverty.

Entrepreneurship education has also grown in popularity as a result of the innovative ideas that students gain from business survival [10] \& [11]. Doing entrepreneurship, of course, requires first instilling highquality qualities and values in oneself before venturing into the realm of entrepreneurship. In a high-quality person, three important factors cannot be separated: entrepreneurial mental attitude, entrepreneurial mental alertness, and entrepreneurial skills and abilities [8] PBL model is an innovative learning model that can provide active learning circumstances for students by exposing them to real-world situations to begin learning [5]. During the Covid-19 pandemic, [12] \& [13] stated that integrating PBL with online learning proved beneficial in accommodating the barriers of face-to-face students at the university level. Electronic-based PBL is effective for developing questioning, thinking, and problem-solving skills, as well as for fostering independent learning.

\section{METHOD}

Quantitative research was used to answer the research questions of this study with multiple linear regression tests. With the following research design, the objective is to analyze whether there is an influence between the problem -based learning model (PBL) with technologybased (X1) and learning motivation (X2) variables on the 
entrepreneurial attitude variable $(\mathrm{Y})$ of students in the Economics Education Department at STKIP PGRI Jombang

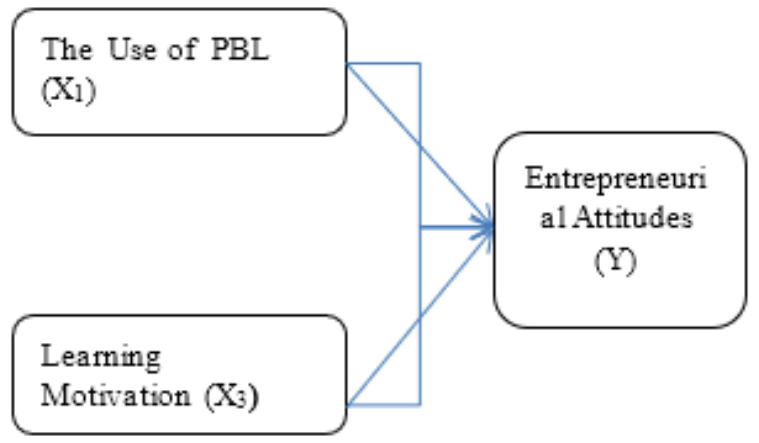

Figure 1. Research Design

It tells :

X1: PBL model with Technology- based

X2: Learning Motivation Y: Entrepreneurial Attitudes

$\mathrm{Y}=\mathrm{a}+\mathrm{b} 1 \mathrm{X} 1+\mathrm{b} 2 \mathrm{X} 2$

In the study, there were 206 students as the population from Economic Education Programme. STKIP PGRI Jombang. A sample of 136 was obtained by using the Slovin formula. Simple random sampling was used for the sampling procedure. This study uses multiple regression to see the effect of 2 independent variables, namely the PBL model with technology-based (X1) and learning motivation (X2) on the dependent variable of entrepreneurial attitudes (Y) [19]

\section{RESULT}

The data that were successfully collected were quantitative data on an interval or ordinal measurement scale by the research design developed. The information in question was gathered from 136 students enrolled in the Economics Education Department at STKIP PGRI Jombang. The result of descriptive statistic is presented in the following:

Table1. Descriptive Statistic

\begin{tabular}{|l|c|c|c|}
\hline & Mean & Std. Deviation & $\mathrm{N}$ \\
\hline $\begin{array}{l}\text { Entrepreneurship } \\
\text { Attitudes }\end{array}$ & 3.3018 & .04047 & 136 \\
\hline PBL & 4.5006 & .03444 & 136 \\
\hline & 4.1610 & .14179 & 136 \\
\hline Motivation & & & \\
\hline
\end{tabular}

According to table 1 , there are 136 data points with an average entrepreneurshi attitude 3.3018 with standart deviation 0.04047. Average of PBL 4.50006 with standart deviation 0.03444 and the last average motivation 4.1610 with standart deviation 0.14179 .

Table 2. Model Summary

\begin{tabular}{|l|r|r|r|r|}
\hline Model & $\mathrm{R}$ & R Square & \multicolumn{1}{c|}{$\begin{array}{c}\text { Adjusted R } \\
\text { Square }\end{array}$} & $\begin{array}{c}\text { Std. Error of the } \\
\text { Estimate }\end{array}$ \\
\hline 1 & $.400^{\mathrm{a}}$ & .160 & .147 & .03737 \\
\hline
\end{tabular}

a. Predictors: (Constant), Motivation, PBL

b. Independent variable: Entrepreneurial Attitudes

According to table $2 \mathrm{R}$ square of 0.160 showing the magnitude of influence of $16 \%$ on the entrepreneurial attitudes of the variable PBL model with technology based and motivation of learning. The low value of $\mathrm{R}$ square is caused by the small number of samples and 84 percent is due to other independent variables not considered in this study so many other variables outside of PBL and motivation that affect entrepreneurial attitudes.

\section{Hypothesis Testing}

Hypothesis testing is carried out to determine the effect of the independent variable on the dependent variable either partially or simultaneously.

\section{Simultaneous Test}

According to table 3 , the significance of $\mathrm{F}$ is 0.000 , indicating that the technology-based PBL Model variable and learning motivation both influence the entrepreneurial attitude of STKIP PGRI Jombang students enrolls in the Economics Education Department.

Tabel 3. ANOVA

\begin{tabular}{|l|r|r|r|r|r|}
\hline Model & $\begin{array}{c}\text { Sum of } \\
\text { Squares }\end{array}$ & Df & $\begin{array}{r}\text { Mean } \\
\text { Square }\end{array}$ & F & Sig. \\
\hline 1 Regression & .035 & 2 & .018 & 12.634 & .000 \\
Residual & .186 & 133 & .001 & & \\
Total & .221 & 135 & & & \\
\hline
\end{tabular}

a. Predictors: (Constant), Motivation, PBL

b. Independent variable: Entrepreneurial Attitudes

\section{Partial Test}

Table 4 shows that technology-based PBL model variable affects on entrepreneurial attitudes, as evidenced by the $\mathrm{t}$ significance value of $0.000<0.05$, and the $\mathrm{t}$ significance value of $0.017<0.05$ for the learning motivation variable, indicating that the learning motivation variable affects on entrepreneurial attitudes of Economics Education Department at STKIP PGRI Jombang. 
Tabel 4 Coefficients

\begin{tabular}{|l|r|r|r|r|}
\hline \multirow{2}{*}{ Model } & \multicolumn{3}{|l|}{ Unstandardized Coefficients } & \multicolumn{2}{|l|}{} \\
\cline { 2 - 5 } & $\mathrm{B}$ & \multicolumn{1}{c|}{ Std. Error } & $\mathrm{t}$ & Sig. \\
\hline 1 (Constant) & 1.271 & .427 & 2.979 & .003 \\
\hline $\mathrm{PBL}$ & .401 & .094 & 4.283 & .000 \\
\hline Motivation & .055 & .023 & 2.414 & .017 \\
\hline
\end{tabular}

Based on table 4 it can also be seen that the multiple regression model is as follows:

$\mathrm{Y}=\mathrm{a}+\mathrm{X} 1+\mathrm{b} 2 \mathrm{X} 2$

$\mathrm{Y}=1,271+0,401 \mathrm{X} 1+0,055 \mathrm{X} 2$

According to the regression model, the constant value of 1.271 indicates that when the variables X1 (PBL model with technology based) and X2 (learning motivation) are constant or zero, the value of the Y variable (entrepreneurial attitudes) is 1.271. The coefficient value of X1 (technology-based PBL model) is 0.401 , which means that if $\mathrm{X} 1$ increases by one unit, the $\mathrm{Y}$ value increases by 0.401 units, assuming the $\mathrm{X} 2$ variable is held constant. The X2 coefficient (learning motivation) has a value of 0.055 , which means that if $\mathrm{X} 2$ increases by one unit, the $\mathrm{Y}$ value will increase by 0.055 units, assuming $\mathrm{X} 1$ remains constant.

\section{DISCUSSION}

The results of the first study indicated that a lecturer could use PBL model with technology-based in various groups of students during the learning process. Lecturers who delivered entrepreneurship material to students using PBL model with technology were less concerned with the theory and more concerned with practical applications. Students were exposed to a variety of lecture materials that require them to interact with realworld practical applications, both in groups and individually.

The entrepreneurial attitude of the students of STKIP PGRI Jombang in economics department is influenced by these skill of an entrepreneurship lecturer by using PBL model with technology-based in solving entrepreneurial problem and providing motivation in learning process. The learning model is one of the supports for the success of teaching and learning activities; good lecturers in teaching are equipped with media and learning models that are appropriate for entrepreneurial material creating smart students. One of the innovations in the digital era is PBL model with technology-based, which is extremely beneficial to lecturers and students in lectures. It is the best model for learning entrepreneurship because many entrepreneurial, economic, social, cultural, and other problems require sophisticated thinking so that students can take an active role in learning to solve problems.
E- PBL is a new adaptive environment that promotes dialogic learning. The entrepreneur course successfully blends student diversity in learning styles and learning interests, as well as students' achievement with appropriate technology, to enable students to participate in team-based evaluations (chat, discussion, and online). The (E-PBL) model is one approach to overcoming this problem. It is an innovative learning method that can provide students with active learning conditions in realworld situations where students are required to learn through direct experience with problems.

There are several relevant studies related to the above discussion. [14] found that Web-based learning is a type of learning activity that makes use of website media (website e) that is accessible via the internet network. Web-based learning, also known as "web-based learning," is a type of electronic learning application (elearning). Various existing online systems like as Zoom, Google Classroom, e-mail, and so on can be used to facilitate online classrooms. Boredom in learning can be reduced by using an engaging and exciting learning paradigm. To avoid monotony, students who learn online require a variety of learning styles [15].

The first step is to decide on the type of learning that will be offered away in advance. At this stage, a needs analysis is performed to determine which domains will be affected by this learning process, whether cognitive, psychomotor, or affective. The learning or training objectives are grouped in this web learning process so that program development can determine which types of cognitive abilities each requires delivery. various information, exercises, and judgments.

The second step in selecting a learning process is to determine the most important type of web-based learning that will meet the goals that must be met. Assess the learning domain that represents the aim, namely cognitive, determine the level of cognitive capacity, and check whether it means highly structured or ill-structured learning difficulties to determine which sort of webbased learning is the most suited.

Finally, examine the four types of web-based learning and choose the learning objectives based on the learning objectives and the learning objectives to be presented.

The results of this study showed that that PBL model with technology-based in entrepreneurship courses can make students understand entrepreneurship course material more easily by using the appropriate learning model. It has a positive influence on how people understand the material, rather than just memorizing, which is easily forgotten. However, by using the learning model, students are trained to solve problems that arise either from assignments given by lecturers or from observing cases that occur in the community. Students can then provide what solutions to take to these problems; this is a phase in which students learn to think at higher 
levels. The digital era as it exists today must be used as effectively as possible in the field of education. One of the innovations that helps lecturers and students learn entrepreneurial attitudes is the technology-based learning model.

These results are supported by [5]; [16] \&[17]. They stated that Motivation is a condition of cognitive arousal that causes a person to make a "choice to act" as a result of "continued intellectual and/or physical effort" to achieve some of their "previously defined goals" [15]. Student achievement is also influenced by motivational factors such as teaching styles and learning motivation. The positive interplay of learning events boosts motivation and encourages people to respond to difficulties in their environment. Sources of information are important for developing attitudes. Aside from textbook information and possibly empirical facts, lecturers are a source of learning. The accuracy of information sources has a significant effect on the development of student confidence. Lecturers play an important role in developing attitudes because they communicate directly with students while also becoming a preference for them. The expected learning model requires the use of multiple sources of information. Students can make choices based on their interests, motivations and talents through various sources of information. Students can therefore find their knowledge and information to analyze situations and facts to obtain values that are useful for their lives.

It cannot be denied that PBL model with technologybased can shape students to work on authentic challenges in order to gather their information, build inquiry and higher-order thinking skills, and promote independence and self-confidence. " This finding is supported by previous research, including [5]; [7], [8] \& [9]. Several studies that show that student benefits are affected by PBL model with technology-based. According to the results of the multiple linear regression test, the PBL model with technology-based and learning motivation affected entrepreneurial attitudes.

This showed that a lecturer's learning process could employ the problem -based learning(PBL) model with technology-based in a variety of student groups, including those with very high, high, medium, low, and very low motivation. In other words, the Economics Education Department students of STKIP PGRI Jombang who were taught by using PBL model with technologybased in the learning process was based on the learning method and level of student learning motivation. The use of PBLmodel with technology-based was expected to increase learning motivation and in turn, improve the entrepreneurial attitude of students. The use of PBL model with technology-based in this study, therefore, has a positive impact on undertaking attitudes of students. It is therefore suggested that the students should be aware of their study motivation using technology-based problem-based learning in the hope that PBL with technology-based is the best used and ultimately a process that is effective and efficient.

The results of the analysis showed that $\mathrm{R}$ Square is 0.160 or $16 \%$, meaning that entrepreneurial attitudes in the Economics Education Department students of STKIP PGRI Jombang were influenced by the use of Problem Based Learning (PBL) model with technology-based and learning motivation by $16 \%$. While the R Square which could not be explained by multiple linear regression models is $(100 \%-16 \%)=84 \%$, meaning that $84 \%$ of the achievement of student entrepreneurial attitudes was not influenced by the use of PBL model with technologybased and the level of learning motivation was considered to be influenced by other factors such as lecturers 'ability in teaching, campus environmental conditions, talents, student stimuli or stimulants, socioeconomic conditions, students' initial abilities and no less important is the attitude of parents towards their children's education. Therefore, in addition to the use of PBL model with technology-based and learning motivation, it is necessary to examine the relationship of these factors with the attitudes of student entrepreneurial achievement in entrepreneurship learning, especially at STKIP PGRI Jombang.

\section{CONCLUSION}

The Entrepreneurial Attitudes of Economics Education Department students at STKIP PGRI Jombang were influenced by the application of the problem-based learning (PBL) Model with technology-based and Learning Motivation. It can be concluded that 1) there is an effect of the problem-based learning (PBL) model with technology-based on entrepreneurial attitudes 2) there is an influence of Learning motivation on entrepreneurial attitudes and 3) there is an influence on entrepreneurial attitudes simultaneously on the problem based Learning model with technology-based and learning motivation. In addition, the researchers produced guide book for E-Learning based on problem based learning (PBL) model to enhance the students' entrepreneurial attitude and achievement.

\section{Suggestion}

Based on the conclusion from the results of this study above, we have some suggestion to do for further research for the next researchers as the following

The use of technology-based Problem Based Learning model can improve student entrepreneurial attitudes. Ideally, college lecturers, particularly those in the economic education study program STKIP PGRI Jombang, can improve the teaching and learning process as much as possible by using technology-based Problem Based Learning, so that the teaching and learning process can be achieved optimally. And active, creative and innovative students 
The level of student learning motivation affects entrepreneurial attitudes in entrepreneurship learning, particularly in the economic education study program STKIP PGRI Jombang, so it is suggested that at the beginning of the lesson, an initial questionnaire be given to determine the level of student motivation for the material to be taught. Knowing the level of student motivation and student learning methods allows the form of learning (both models, media, systems, etc.) to be chosen with the expectation that it will encourage students to study groups in the learning process, particularly student learning. groups with low motivation and fewer learning methods efficient, so that learning objectives can be achieved optimally.

Because factors such as lecturers' ability to teach, social environmental conditions, socioeconomic conditions, student backgrounds, and students' initial abilities have not been studied by researchers, and this is the researcher's weakness, we suggest that additional researchers conduct research on these factors.

\section{REFERENCES}

[1] E. Kurniati, Dwi, Kewirausahaan Industri. 2015.

[2] Zakaria, M. I., Maat, S. M., \& Khalid, F. (2019). A Systematic review of problem based

[3] learning in education. Creative Education, Vol.10No.12, 2671-2688. doi:http://dx.doi.org/10.4236/ce.2019.1012194

[4] Haley, C. M., \& Brown, B. (2020). Adapting problem based learning curricula to a virtual environment. J Dent Educ, 1, 2. doi:http://dx.doi.org/10.1002/jdd.12189

[5] Miller, E. C., Reigh, E., Berland, L., \& Krajcik, J. (2021). Supporting equity in virtual science instruction through project-based learning: Opportunities and challenges in the era of COVID19. Journal of Science Teacher Education, 32(6), 642-663.

doi:https://doi.org/10.1080/1046560X.2021.18735 49

[6] Munawaroh (2020). The Influence of problembased learning model as learning method, and learning motivation on entrepreneurial attitude," .International Journal of Instruction, 13 (2), 431-444.

[7] Mahendra, A. M., Djatmika, E. T., \& Hermawan, A. (2017). The Effect of Entrepreneurship Education on Entrepreneurial Intention Mediated by Motivation and Attitude among Management Students, State University of Malang, Indonesia. International Education Studies, 10(9), 61-69. https://doi.org/10.5539/ies.v10n9p61
[8] M. Mutmainah, D. Dusalan, and M. Muchlis, "Pengaruh pembelajaran problem based learning terhadap kreativitas matematika siswa pada kelas viii unggulan mtsn 1 makassar," supermat (JURNAL Pendidik. Mat., vol. 2, no. 2, 2019, https://doi.org/10.33627/sm.v2i2.97

[9] Miller, E. C., Reigh, E., Berland, L., \& Krajcik, J. (2021). Supporting equity in virtual science instruction through project-based learning: opportunities and challenges in the era of COVID19. Journal of Science Teacher Education, 32(6), 642-663.

https://doi.org/10.1080/1046560X.2021.1873549

[10] Iwu, C. G., Opute, P. A., Nchu, R., Eresia-Eke, C., Tengeh, R. K., Jaiyeoba, O., \& Aliyu, O. A. (2021). Entrepreneurship education, curriculum and lecturer-competency as antecedents of student entrepreneurial intention. The International Journal of Management Education, 19(1), 100295. https://doi.org/10.1016/j.ijme.2019.03.007

[11] Beech, N., \& Anseel, F. (2020). COVID-19 and Its Impact on Management Research and Education: Threats, Opportunities and a Manifesto. British Journal of Management, 31(3), 447-449. doi:https://dx.doi.org/10.1111\%2F14678551.12421

[12] Duval-Couetil, N., Ladisch, M., \& Yi, S. (2021). Addressing academic researcher priorities through science and technology entrepreneurship education. The Journal of Technology Transfer, 46(2), 288318. doi:https://doi.org/10.1007/s10961-02009787-5

[13] Hendarwati, E., Nurlaela,, L., Bachri,B.S. and Sa'ida, N.(2021). Collaborative problem based learning integrated with online learning," Int. J. Emerg. Technol. Learn, 16 (13), 29-39. https://doi.org/10.3991/ijet.v16i13.24159

[14] Kladchuen, R. and Srisomphan, J.(2021). The synthesis of a model of problem-based learning with the gamification concept to enhance the problem- solving skills for high vocational certificate," Int. J. Emerg. Technol. Learn., 16 (14), 4-21. https://doi.org/10.3991/ijet.v16i14.20439

[15] Suhada, I., Kurniati, T., Pramadi, A., Listiawati, M., Biologi, P. P., Gunung, S., \& Bandung, D. (2020). Pembelajaran Daring Berbasis Google Classroom Mahasiswa Pendidikan Biologi Pada Masa Wabah Covid-19 (Pembelajaran Daring Berbasis Google Classroom Mahasiswa Pendidikan Biologi Pada Masa Wabah Covid-19). Digital Library UIN Sunan Gunung Jati, 2019, 1-9. http://digilib.uinsgd.ac.id/30584/ 
[16] Widiyono, A. (2020). Efektifitas Perkuliahan Daring (Online) pada Mahasiswa PGSD di Saat Pandemi Covid 19 (Effectiveness of Online Lectures for PGSD Students during the Covid 19 Pandemic). Jurnal Pendidikan, 8(2), 169-177. https://doi.org/10.36232/pendidikan.v8i2.458

[17] Wen, X., \& Piao, M. (2020). Motivational profiles and learning experience across Chinese language proficiency levels. System, 90, 102216. https://doi.org/10.1016/j.system.2020.102216

[18] Escobar Fandiño, F. G., Muñoz, L. D., \& Silva Velandia, A. J. (2019). Motivation and E-Learning English as a foreign language: A qualitative study. Heliyon, $5(9)$, https://doi.org/10.1016/j.heliyon.2019.e02394 